\title{
Administrasi Pendidik dan Tenaga Kependidikan (PTK) 2
}

\author{
Nadya Olivia Perrina \\ Universitas Negeri Padang \\ Indonesia \\ nadyaolivia2509.nogmail.com
}

\begin{abstract}
Abstrak-Educational personnel administration is the entire process of activities that are planned and carried out deliberately and conscientiously as well as carrying out coaching and continuous training of teachers and employees in schools or educational institutions.

Personnel administration, is a series of collaborative processes ranging from planning, organizing, mobilizing and supervising in the field of personnel by utilizing available and efficient resources, so that all school personnel contribute optimally to the achievement of established educational / school goals.
\end{abstract}

Keywords—Konsep dasar administrasi PTK, cuti, proses, gaji.

\section{PENDAHULUAN}

Pada hakikatnya aktivitas pendidikan selalu berlangsung dengan melibatkan unsur subyek atau pihakpihak sebagi aktor penting. Subyek penerima adalah peserta didik sedangkan subyek pemberi adalah pendidik. Seseorang yang menginginkan menjadi pendidik maka ia dipersyaratkan mempunyai kriteria yang di inginkan oleh duni pendidikan. Orang yang merasa terpanggil untuk mendidik maka ia mencintai peserta didiknya dan memiliki perasaan wajib dalam melaksanakan tugasnya disertai dengan dedikasi yang tinggi atau bertanggung jawab.

Kajian tentang pendidik mencakup beberapa hal antara lain pengertian dan sebutan istilah pendidik, kompetensi pendidik, kedudukan pendidik, hakekat tugas dan tanggung jawab guru, profesionalisme guru, organisasi profesi dan kode etik guru.

\section{Metode PENELITIAN}

Artikel ilmiah sesuai kaidahnya disusun denga sistimatis. Pada artikel ini penulis menggunakan metode studi litelatur yaitu mengumpulkan dan merangkum materi yang bersumber dari buku, jurnal, dan sumber lainnya yang terkait dengan ilmu adminstrasi pendidikan.

\section{KAJIAN TEORI DAN PEMBAHASAN}

\section{A. Pembinaan dan Pengembangan Ptk}

Pemamfaatan personil merupakan upaya pelibatan secara aktif para personil dalam kegiatan penyelenggaraan kerja untuk mencapai tujuan lembaga. Pembinaan personil adalah kegiatan yang diarahakan untuk menjamin penyelenggaraan tugas-tugas lembaga/pemerintahan dan pembangunan secara berdaya guna dan berhasil guna. Pengembangan personil adalah upaya peningkatan kemampuan personil dalam melaksanakan tugas-tugasnya untuk mencapai tujuan lembaga. Pengembangan personalia ialah tata cara atau peninjauan kembali untuk menjamin stabilitas kepegawaian. Perkembangan personal merupakan salah satu kegiatan penting bagi kemajuan sekolah.

Keberhasilan program pengembangan personal, di dalam beberapa hal banyak dipengaruhi oleh peranan pimpinannya. Mereka diperlukan mulai dari tahap perencanaan, pelaksanaan dan penyelesaian pogram itu. Walaupun pimpinan sudah memberikan kesempatan baik dalam menyediakan fasilitas secukupnya, itu semua belum cukup masih ada yang diperlukan dari dia, yaitu kemauan, keseriusan dan kesungguhan di dalam melaksanakan. Dengan singkat dapat dikatakan bahwa manajemen pimpinan merupakan kunci untuk program pengembangan personal ini.

1. Sebab -sebab dilaksanakannya pengembangan personalia

a. Adanya tata cara atau peraturan baru dalam personalia tersebut.

b. Adanya pegawai yang kurang cakap.

c. Adanya mesin-mesin baru.

d. Perlunya penyegaran kembali khususnya pegawai.

2. Tata cara peningkatan mutu karyawan

Peningkatan mutu karyawan dapat dilakuan dengan diadakan suatu latihan dan pendidikan. Latihan adalah suatu kegiatan atau usaha untuk meningkatkan pengetahuan dan ketrampilan seorang pegawai dalam melaksanakan tugas atau pekerjaan tertentu.

Menurut Instruksi Presiden No 15 tahun 1974, latihan adalah bagian pendidikan yang menyangkut poses belajar unuk memperoleh dan meningkatkan ketrampilan di luar sistem pendidikan yang berlaku dalam waktu yang relatif singkat dan dengan metode yang lebih mengutamakan praktik daripada teori.

Latihan yang dilakukan oleh personalia atau pegawai bertujuan agar pegawai bekerja lebih efisien. Selain itu, latihan ini juga dilakukan agar pegawai dapat mengembangkan keahliannya, sehingga pekerjaan apat diselesaikan dengan lebih cepat dan efisien, serta 
mengembangkan sikap dan pengetahuan pegawai. Latihan dan pendidikan dapat diberikan dengan cara:

a. dengan penjelasan dan contoh-contoh kerja dan training.

b. dengan sistem individual atau klasikal.

c. dengan rapat.

d. lokakarya (penjelasan dan pameran)

e. briefing (penjelasan yang bersifat instruksi)

Pembinaan dan pengembanan terhadap staf tidak hanya pada nggota yang baru saja, tetapi juga kepada seluruh staf. Pembinaan harus dilakukan secara terus menerus dan secara sistematis. Pembinaan ini sangat penting karena perkembangan baik perkembangan ilmu pengetahuan, perkembangan teknologi, maupun perkembangan masyarakat dan kebijaksanaankebijaksanaan yang baru.

Jadi dalam rangka meningkatkan efisiensi kerja, masalah pembinaan pegawai menempati kedudukan yang penting. Program pembinaan pegawai meliputi aspek yang cukup luas antara lain mengenai peningkatan kemampuan kerjanya, peningkatan dedikasi, moral dan disiplin kerja serta pengarahan dan pembentukan motif kerja yang obyektif.

Peningkatan kemampuan dan kemahiran kerja dapat ditempuh dengan jalan menambah pengetahuan dan latihan-latihan bagi para personal melalui penataran, tugas belajar, latihan kerja di lingkungan sendiri atau lingkungan lain dan di dalam maupun di luar negeri. Program peningkatan kerja harus diarahkan untuk, memungkinkan tenaga kerja yang tersedia dipergunakan secara berdaya guna dan berhasil guna, menciptakan hubungan kerja yang menyenangkan dan produktif dalam rangka mencapai tujuan, dan meningkatkan perkembangan tenaga kerja sampai batas kemampuan maksimal masing-masing dan sesuai pula dengan perkembangan cara dan peralatan kerja yang terbaru dan terbaik.

Kegiatan-kegiatan administrasi personalia diatas (pemanfaatan, pembinaan, dan pengembangan) merupakan upaya pendayagunaan personil secara optimal. Upaya pendayagunaan personil meliputi kegiatan :

\section{Orientasi Personil}

Merupakan kegiatan yang dimaksudkan untuk memperkenalkan kepada individu/ personil baru tentang keadaan organisasi, supaya mereka dapat berfungsi secara efektif dan menyenangkan pada pekerjaan barunya.

\section{Pendidikan dan Latihan}

Sebagai upaya pengembangan personil menurut PP 1010 tentang pendidikan pelatihan pegawai negeri sipil pasal 1 adalah proses penyelenggaraan belajar mengajar dalam rangka meningkatkan kemampuan PNS. Pendidikan dan latihan PNS terdiri dari: 1) pendidikan dan latihan pra jabatan, 2) pendidikan dan latihan dalam jabatan
3. Penggajian personil

Penggajian PNS diatur dalam peraturan pemerintah nomor 6 tahun 1997. Besarnya gaji pokok seorang PNS ditentukan oleh golongan ruang, pangkat, dan massa kerjanya. Gaji yang diberikan kepada PNS di samping gaji pokok juga ada tunjangan-tunjangan, di antaranya adalah:

a. Tunjangan keluarga. Tunjangan ini terdiri atas tunjangan istri/ suami sebesar $10 \%$ gaji pokok dan tunjangan anak sebesar $2 \%$ dari gaji pokok untuk masing-masing anak (sebanyak-banyaknya 2 anak).

b. Tunjangan pangan. Diberikan seharga $10 \mathrm{~kg}$ beras untuk setiap anggota untuk sebanyak 4 orang dan bagi yang suami/ istrinya juga PNS, maka hanya diberi satu tunjangan.

c. Tunjangan jabatan. Diberikan kepada PNS yang memangku jabatan tertentu. Tunjangan ini dapat berbentuk tunjangan jabatan structural dan tunjangan jabatan fungsional.

d. Tunjangan lain-lain. Diberikan sesuai dengan peraturan pemerintah. PNS termasuk guru diberi kenaikan gaji pokok, kenaikan gaji berkala, kenaikan gaji istimewa.

4. Kenaikan pangkat personil

Kenaikan pangkat adalah penghargaan yang diberikan atas prestasi kerja dan pengabdian PNS terhadap Negara. Meurut PP nomor 99 tahun 2000 jenis kenaikan pangkat PNS adalah sebagai berikut:

a. Kenaikan pangkat regular

b. Kenaikan pangkat pilihan, diberikan kepada PNS yang:

> Menduduki jabatan structural atau jabatan fungsional tertentu

> Menduduki jabatan tertentu yang pengangkatannya ditetapkan dengan keputusan Presiden

$>$ Menunjukkan prestasi kerja luar biasa baiknya

$>$ Menemukan penemuan baru yang bermanfaat bagi Negara

$>$ Diangkat menjadi pejabat Negara

$>$ Melaksanakan tugas belajar dan sebelumnya menduduki jabatan structural atau fungsional

$>$ Telah selesai mengikuti dan lulus tugas belajar

> Dipekerjakan atau diperbantukan secara penuh di luar instansi induknya yang diangkat dalam jabatan pimpinan atau jabatan fungsional tertentu.

c. Kenaikan pangkat anumerta

d. Kenaikan pangkat pengabdian 
5. Cuti personil

Cuti PNS menurut pasal 1 PP nomor 24/ 1976 adalah keadaan tidak masuk kerja yang diijinkan dalam jangka waktu tertentu. Jenis cuti PNS menurut peraturan tersebut adalah:

a. Cuti tahunan

b. Cuti besar

c. Cuti sakit

d. Cuti bersalin

e. Cuti di luar tanggungan Negara

6. Kesejahteraan pegawai

pemerintah juga mengusahakan beberapa hal untuk kesejahteraan pegawai negeri sipil yaitu Taspen, Askes, dan Koperasi

7. Pemindahan

PNS dimungkinkan pindah dari satu tempat ke tempat lainnya karena alas an-alasan tertentu. Pemindahan PNS dapat dibagi atas: pemindahan atas permintaan sendiri, pemindahan tidak atas kemauan sendiri, dan pemindahan atas kepentingan dinas.

8. DP3

Daftar penilaian pelaksanaan pekerjaan (DP3) diatur dengan PP nomor 10 tahun 1979. DP3 merupakan suatu daftar yang memuat hasil penilaian pelaksanaan pekerjaan setiap pegawai selama satu tahun (Januari sampai Desember) dibuat oleh pejabat penilai. Unsur-unsur yang dinilai dalam DP3 ini adalah kesetiaan, prestasi kerja, tanggung jawab, ketaatan, kejujuran, kerjasama, prakarsa dari kepemimpinan. Nilai pelaksanaan pekerjaan dinyatakan dengan sebutan dan angka sebagai berikut:
a. Amat baik $=90-100$
b. Baik $=76-90$
c. Cukup =61-75
d. Sedang $=51-60$
e. Kurang = kurang dari 50

Sebagai suatu organisasi yang bertumbuh, lembaga pendidikan selalu membutuhkan perhatian kedalam yaitu terhadap dirinya sendiri. Perhatian itu tertuju pada usaha mempertahankan kelangsungan hidup, peningkatan, dan agen pembaruan. Salah satu aktivitas untuk mencapai usaha itu ialah dengan jalan melakukan pengembangan personalia pendidikan. Pengembangan ini terutama untuk mencegah pemakaian pengetahuan yang sudang usang dan pelaksanaan tugas yang sudah ketinggalan zaman.

Apabila seorang guru maupun karyawan pendidikan yang belum terampil dan ahli dalam bidangnya dalam mempelajari suatu keahliannya, nyata sekali bahwa ia mengalami suatu proses belajar yang rumit. Berbagai prinsip yang berguna sebagai pedoman dalam proses keterampilan, pengetahuan dan sikap adalah sebagai berikut:

a. Motivasi

b. Laporan kemajuan c. Peneguhan

d. Latihan

e. Perbedaan individual

Jenis pengembangan dikelompokan atas pengembangan secara informal dan pengembangan secara formal.

1) Pengembangan secara informal, yaitu guru dan karyawan atas keinginan dan usaha sendiri melatih dan mengembangkan dirinya dengan mempelajari buku-buku atau literatul yang berhubungan dengan keterampilan dan keahliannya.

Pengembangan secara informal menunjukkan bahwa guru dan karyawan tersebut berkeinginan keras untuk maju dengan cara meningkatkan kemampuan kerjanya. Hal ini bermanfaat bagi sekolah karena prestasi kerja guru semakin besar, disamping efisensi dan produktifitasnya semakin baik.

2) Pengembangan secara formal, yaitu guru dan karyawan ditugaskan dari pihak sekolah untuk mengikuti pendidikan dan latihan, baik yang dilakukan dari pihak sekolah untuk mengikuti pendidikan dan latihan, baik yang dilakukan dari pihak sekolah itu sendiri maupun yang dilaksanakan oleh lembaga-lembaga pendidikan.

\section{B. KENAIKAN PANGKAT PTK}

Kenaikan pangkat adalah penghargaan yang diberikan atas prestasi kerja dan pengabdian PNS terhadap Negara.

1. Sistem Kenaikan Pangkat

Nama dan susunan pangkat serta golongan/ruang pegawai dari yang terendah sampai yang tertinggi adalah sebagaimana yang berlaku pada Pegawai Negeri Sipil. Kenaikan pangkat dilaksanakan berdasarkan sistem kenaikan pangkat reguler, sistem kenaikan pangkat penyesuaian, sistem kenaikan pangkat istimewa, dan sistem kenaikan pangkat pengabdian.

2. Masa Kenaikan Pangkat

Kenaikan pangkat pegawai ditetapkan pada tanggal 1 Januari, 1 April, 1 Juli, dan 1 Oktober setiap tahun, kecuali ditentukan lain dalam peraturan ini. Masa kerja untuk kenaikan pangkat pertama dihitung sejak secara nyata seorang pegawai melaksanakan tugas pekerjaan setelah pengangkatannya sebagai calon pegawai. 
3. Kenaikan Pangkat Reguler

A. Kenaikan pangkat reguler diberikan kepada pegawai tanpa memperhitungkan jabatan struktural atau jabatan fungsional.

1) Kenaikan pangkat reguler bagi pegawai administratif diberikan apabila pegawai yang bersangkutan telah memenuhi syarat:

a. telah 4 (empat) tahun menduduki pangkat yang dimilikinya dan setiap unsur penilaian pelaksanaan pekerjaan sekurang-kurangnya bernilai baik, kecuali unsur kesetiaan harus bernilai amat baik dalam 2 (dua) tahun terakhir, atau

b. telah 5 (lima) tahun menduduki pangkat yang dimilikinya dan penilaian pelaksanaan pekerjaan rata-rata bernilai cukup, kecuali unsur kesetiaan harus bernilai amat baik dalam 2 (dua) tahun terakhir, dan tidak ada unsur penilaian pelaksanaan pekerjaan yang bernilai kurang.

c. kenaikan pangkat sebagaimana dimaksud diberikan sepanjang tidak melampaui pangkat atasan langsungnya.

2) Kenaikan pangkat reguler bagi pegawai yang menduduki jabatan fungsional tertentu, yang untuk kenaikan pangkatnya, di samping harus memenuhi syarat-syarat yang ditentukan, diharuskan memenuhi angka kredit, dapat diberikan setiap kali setingkat lebih tinggi, apabila yang bersangkutan :

a. Sekurang-

kurangnya telah 2 (dua) tahun menduduki pangkat yang dimilikinya, dan setiap unsur penilaian pelaksanaan pekerjaan sekurangkurangnya bernilai baik, kecuali unsur kesetiaan harus bernilai amat baik selama 2 (dua) tahun terakhir, atau

b. Sekurang-kurangnya telah 3 (tiga) tahun menduduki pangkat yang dimilikinya, dan penilaian pelaksanaan pekerjaan rata-rata bernilai cukup, kecuali unsur kesetiaan harus bernilai amat baik selama 2 (dua) tahun terakhir, dengan ketentuan tidak ada unsur penilaian pelaksanaan pekerjaan yang bernilai kurang.

3) Ketentuan mengenai angka kredit untuk kenaikan pangkat reguler ditetapkan berdasarkan Keputusan Menteri Negara Koordinator Bidang Pengawasan Pembangunan dan Pendayagunaan Aparatur Negara atau pejabat lain yang diberi wewenang berdasarkan ketentuan yang berlaku\}

4) Pegawai yang memiliki Ijazah Doktor (S3) atau Spesialis II dapat dinaikkan pangkatnya setingkat lebih tinggi menjadi Penata, golongan/ruang III/c, apabila : a. sekurang-kurangnya telah 2 (dua) tahun menduduki pangkat Penata Muda Tingkat I, golongan ruang III/b, dan

b. setiap unsur penilaian pelaksanaan pekerjaan sekurang-kurangnya bernilai baik dalam 1 (satu) tahun terakhir.

Kenaikan pangkat reguler bagi pegawai sebagaimana dimaksud di atas diberikan paling tinggi sampai dengan :

(a) Pengatur Muda Tingkat I, golongan/ruang II/b, bagi yang memiliki Surat Tanda Tamat Belajar atau Ijazah Sekolah Dasar atau yang sederajat.

(b) Pengatur Tingkat I, golongan/ruang II/d bagi yang memiliki Surat Tanda Tamat Belajar atau Ijazah Sekolah Lanjutan Tingkat Pertama atau Ijazah lain yang sederajat.

(c) Penata , golongan/ruang III/a bagi yang memiliki Surat Tanda Tamat Belajar atau Ijazah Sekolah Kejuruan Tingkat Pertama 4 (empat) tahun atau Ijazah lain yang sederajat.

(d) Penata Muda Tingkat I, golongan/ruang III/b bagi yang memiliki Surat Tanda Tamat Belajar atau Ijazah Sekolah Lanjutan Tingkat Atas, Sekolah Kejuruan Tingkat Atas non-guru 3 (tiga) tahun, Ijazah Diploma I, Sekolah Kejuruan Tingkat Atas Guru 3 (tiga) tahun, Akta I, atau Ijazah lain yang sederajat.

(e) Penata Tingkat I, golongan/ruang III/d bagi yang memiliki Ijazah Sekolah Guru Pendidikan Luar Biasa, Ijazah Diploma II, Bakaloreat, Akta II.

(f) Penata Tingkat I, golongan/ruang III/d bagi yang memiliki Ijazah Sarjana Muda, Ijazah Diploma III Politeknik, Diploma III, Akademi.

(g) Pembina , golongan/ruang IV/a bagi yang memiliki Ijazah Sarjana (S1) atau Ijazah Diploma IV.

(h) Pembina Tingkat I, golongan/ruang IV/b bagi yang memiliki Ijazah Magister (S2), Ijazah Profesi Dokter, Apoteker, Akuntan, atau Ijazah Spesialis I.

(i) Pembina Utama Madya, golongan/ruang IV/d bagi yang memiliki Ijazah Doktor (S3) atau Ijazah Spesialis II.

4. Kenaikan Pangkat Penyesuaian

1) Kenaikan pangkat penyesuaian diberikan kepada pegawai yang memperoleh Surat Tanda Tamat Belajar atau Ijazah atas usaha sendiri atau atas penugasan dari Yayasan.

2) Kenaikan pangkat penyesuaian diberikan kepada pegawai yang memperoleh Surat Tanda Tamat Belajar atau Ijazah :

a. Sekolah Lanjutan Tingkat Pertama atau yang sederajat dan masih berpangkat Juru Muda 
Tingkat I, golongan ruang I/b ke bawah, dapat dinaikkan pangkat penyesuaian menjadi Juru, golongan ruang $\mathrm{I} / \mathrm{c}$.

b. Sekolah Lanjutan Tingkat Atas, Diploma I, atau yang sederajat dan masih berpangkat Juru Tingkat I, golongan/ruang I/d ke bawah, dapat dinaikan pangkat penyesuaian menjadi Pengatur Muda, golongan/ruang II/a.

c. Sekolah Guru Pendidikan Luar Biasa, Diploma II, Bakaloreat, atau Akta II dan masih berpangkat Pengatur Muda, golongan/ruang II/a ke bawah, dapat dinaikkan pangkatnya menjadi Pengatur Muda Tingkat I, golongan/ruang II/b.

d. Sarjana Muda, Akademi, atau Diploma III dan masih berpangkat Pengatur Muda Tingkat I, golongan/ruang II/b ke bawah, dapat dinaikkan pangkat penyesuaian menjadi Pengatur, golongan ruang $\mathrm{II} / \mathrm{c}$.

e. Ijazah Sarjana (S1), atau Ijazah Diploma IV, dan masih berpangkat Pengatur Tingkat I, golongan/ruang II/d ke bawah, dapat dinaikkan pangkat penyesuaian menjadi Penata Muda, golongan/ruang III/a.

f. Dokter, profesi Apoteker, Akuntan, dan Ijazah yang sederajat, atau Spesialis I dan masih berpangkat Penata Muda, golongan/ruang III/a ke bawah, dapat dinaikkan pangkat penyesuaian menjadi Penata Muda Tingkat I, golongan/ruang III/b.

g. Doktor atau Spesialis II dan masih berpangkat Penata Muda Tingkat I, golongan/ruang III/b ke bawah, dapat dinaikkan pangkat penyesuaian menjadi Penata, golongan/ruang III/c.

3) Kenaikan pangkat sebagaimana dimaksud dalam peraturan kepegawaian dapat diberikan kepada pegawai yang bersangkutan apabila :

a. diangkat dalam jabatan/diberi tugas yang memerlukan pengetahuan/keahlian yang sesuai dengan ijazah yang diperoleh,

b. sekurang-kurangnya telah 1 (satu) tahun menduduki pangkat terakhir, dan

c. setiap unsur penilaian pelaksanaan pekerjaan sekurang-kurangnya bernilai baik dalam 1 (satu) tahun terakhir.

5. Kenaikan Pangkat Istimewa

1) Kenaikan pangkat istimewa diberikan kepada pegawai yang telah lulus tugas belajar dan lulus dengan tepat waktu yang ditentukan dan memperoleh :

a. Ijazah Sarjana Muda, Ijazah Akademi, atau Ijazah Diploma III dan masih berpangkat Pengatur Muda Tingkat I, golongan/ruang II/b ke bawah, dinaikkan pangkatnya menjadi Pengatur, golongan ruang II/c. b. Ijazah Sarjana (S1) atau Ijazah Diploma IV dan masih berpangkat Pengatur Muda Tingkat I ke bawah, golongan/ruang II/d ke bawah, dinaikkan pangkatnya menjadi Penata Muda, golongan/ruang III/a.

c. Ijazah Dokter, Ijazah Profesi Apoteker, Akuntan, dan Ijazah lain yang sederajat, Ijazah Magister (S2), atau Ijazah Spesialis I dan masih berpangkat Penata Muda, golongan/ruang III/a ke bawah, dinaikkan pangkatnya menjadi Penata Muda Tingkat I, golongan/ruang III/b.

d. Ijazah Doktor (S3) atau Ijazah Spesialis II dan masih berpangkat Penata Muda Tingkat I, golongan/ruang III/b ke bawah dinaikkan pangkatnya menjadi Penata, golongan/ruang III/c.

2) Pegawai yang apabila sebelum mengikuti tugas belajar kepangkatannya telah sesuai dengan kepangkatan penyesuaian, diberikan kenaikan pangkat istimewa setingkat lebih tinggi dari pangkatnya terakhir.

3) Kenaikan pangkat diberikan apabila :

a. sekurang-kurangnya telah 1 (satu) tahun menduduki pangkat terakhir, dan

b. setiap unsur penilaian pelaksanaan pekerjaan sekurang-kurangnya bernilai baik dalam (satu) tahun terakhir.

6. Kenaikan Pangkat Anumerta

1) Pegawai yang dinyatakan tewas, diberikan kenaikan pangkat anumerta setingkat lebih tinggi.

2) Kenaikan pangkat anumerta berlaku mulai tanggal pegawai yang bersangkutan dinyatakan tewas oleh yang berwajib. Calon pegawai yang tewas, diangkat menjadi pegawai dalam dinas tetap Yayasan terhitung mulai awal bulan yang bersangkutan tewas, dan berlaku ketentuan sebagaimana dimaksud dalam Peraturan.

3) Keputusan kenaikan pangkat anumerta diberikan oleh Pengurus Yayasan atas usul Pejabat yang berwenang.

4) Keputusan kenaikan pangkat anumerta diberikan sebelum pegawai yang tewas tersebut dimakamkan.

5) Akibat keuangan dari kenaikan pangkat anumerta baru timbul setelah keputusan kenaikan tersebut ditetapkan oleh Pengurus Yayasan.

6) Akibat keuangan dari kenaikan pangkat anumerta dibebankan kepada unit karya yang bersangkutan.

7. Kenaikan Pangkat Pengabdian

1) Kenaikan pangkat pengabdian adalah kenaikan pangkat setingkat lebih tinggi dari pangkat terakhir sebagai penghargaan bagi yang telah mencapai batas usia pensiun dan akan mengakhiri masa jabatannya sebagai pegawai organik dengan hak pensiun. 
2) Kenaikan pangkat pengabdian sebagaimana dalam peraturan kepegawaian, apabila yang bersangkutan memenuhi syarat-syarat sebagai berikut :

a. Memiliki masa kerja golongan sekurangkurangnya sebanyak 25 (dua puluh lima) tahun terus menerus di Yayasan atau unit karya di lingkungan Yayasan.

b. Penilaian pelaksanaan pekerjaan rata-rata bernilai baik selama 1 (satu) tahun terakhir, sebelum ia dibebaskan dari jabatannya serta tidak ada unsur penilaian pelaksanaan pekerjaannya yang bernilai kurang.

3) Keputusan kenaikan pangkat pengabdian diberikan oleh Pengurus Yayasan atas usul Pejabat yang berwenang dengan disertai alasan-alasannya.

\section{EVALUASI KINERJA PTK}

Evaluasi Kinerja Karyawan adalah kegiatan yang mengkaji kinerja karyawan selama melaksanakan pelayanan administrasi akademik dan pelayanan laboratorium. Manual prosedur ini bertujuan menjamin terlaksananya kegiatan mendapatkan data dan informasi tentang kepuasan mahasiswa terhadap kinerja karyawan bagian administrasi dan laboratorium, secara cepat, periodik, dan tepat.

1. Tujuan Penilaian Kinerja

Tujuan diadakannya penilaian kinerja bagi para karyawan dapat kita ketahui dibagi menjadi dua, yaitu:

\section{a. Tujuan evaluasi}

Seorang manajer menilai kinerja dari masalalu seorang karyawan dengan menggunakan ratings deskriptif untuk menilai kinerja dan dengan data tersebut berguna dalam keputusan-keputusan promosi. demosi, terminasi dan kompensasi.

b. Tujuan pengembangan

Seorang manajer mencoba untuk meningkatkan kinerja seorang karyawan dimasa yang akan datang.

Sedangkan tujuan pokok dari si stem penilaian kinerja karyawan adalah: sesuatu yang menghasilkan informasi yang akurat dan valid berkenaan dengan prilaku dan kinerja anggota organisasi atau perusahaan.

2. Manfaat penilaian kinerja karyawan

Pada umumnya orang-orang yang berkecimpung dalam manajemen sumber daya manusia sependapat bahwa penilaian ini merupakan bagian penting dari seluruh proses kekaryaan karyawan yang bersangkutan. Hal ini penting juga bagi perusahaan dimana karyawan tersebut bekerja. Bagi karyawan, penilaian tersebut berperan sebagai umpan balik tentang berbagai hal seperti kemampuan, kelebihan, kekurangan, dan potensi yang pada gilirannya bermanfaat untuk menentukan tujuan, jalur, rencana dan pengembangan karir.

Dan bagi organisasi atau perusahaan sendiri, hasil penilaian tersebut sangat penting artinya dan peranannya dalam pengambilan keputusan tentang berbagai hal, seperti identifikasi kebutuhan program pendidikan dan pelatihan, rekruitment, seleksi, program pengenalan, penempatan, promosi, sistem imbalan dan berbagai aspek lain dari proses dari manajemen sumber daya manusia secara efektif.

3. Merancang system penilaian inerja karyawan

Ada beberapa jenis penilaian kinerja karyawan seperti system tradisional, penilaian diri, penilaian oleh atasan, dan penilaian 360 derajat (umpan balik). Penilaian kinerja karyawan umumnya dilakukan secara formal atau terstruktur. Apabila dilakukan secara informal, manajer dapat bertemu dengan para anggota tim untuk mendiskusikan kinerja karyawan dalam periode tertentu dalam suasana rileks dan tidak kaku. Baik secara formal maupun informal, perlu ditelaah beragam faktor yang berpengaruh terhadap kinerja karyawan.

Perlu dinilai apakah keterkaitan tujuan perusahaan dan tujuan karyawan telah tercapai. Perlu dilakukan bagaimana menyediakan unsur pendukung agar kedua tujuan itu tercapai. Bagaimana secara rutin dilakukan penelaahan apa yang telah dicapai karyawan dan kelompok karyawan tanpa harus menunggu timbulnya masalah. Selain itu penilaian termasuk dengan cara diskusi pun dilakukan untuk merumuskan harapanharapan masa depan dan faktor-faktor apa saja yang perlu diperbaiki dan dikembangkan. Apabila dianggap perlu ada peninjauan kembali tujuan yang telah disusun dan menyusun langkah-langkah operasional yang lebih efektif. Karena itu perlu ada manajemen penilaian kinerja yang sistematis.

Proses perancangan sistem penilaian melibatkan: manajer, karyawan dan ahli sumberdaya manusia dalam membuat keputusan tentang:

$>$ Isi dari pengukuran : ada tiga pilihan terkait dengan kinerja

$>$ Fokus penilaian : outcome yang langsung terkait dengan misi dan tujuan organisasi dan kebutuhan pelanggan; penggunaan waktu, tingkat kepuasan pelanggan dsb,

> Jenis kinerja : contoh pekerjaan manajer dilihat dari keberhasilan menerapkan model perencanaan dan pengorganisasian; ada enam kriteria
a. kualitas proses dan hasil,
b. jumlah hasil, nilai hasil persiklus waktu tertentu,
c. waktu yang dipakai,
d. cost efektif yaitu manajemen sumberdaya secara efisien (biaya-penerimaan),
e. derajad kebutuhan supervisi dan
f. pengaruh antarpersonal seperti harga diri, persahabatan dan kerjasama.

4. Perumus level kinerja : tiga bentuk berbeda

a. kondisi sifat; sangat puas sampai sangat tidak puas,

b. deskripsi perilaku atau kejadian kritis; apa yang terjadi ketika karyawan dinilai, dan 
c. outcome atau hasil; jumlah unit produk, jumlah keluhan pelanggan, jumlah unit produk yang ditolak; jumlah ketidakhadiran karyawan.

5. Proses pengukuran

Ada minimum tiga pilihan dalam proses ini :

(a) tipe skala ukuran; kebanyakan bersifat ordinal, peringkat kualitatif; interval,

(b) tipe instrumen penyusunan peringkat; dapat membandingkan antarperingkat kinerja dan antar personalia, dan

(c) metode penghitungan skor.

Karakteristik administrasi penilaian kinerja :

1) frekuensi dan waktu bervariasi bergantung pada fungsi kegiatan; tiap bulan-dua bulan selama enam dan 12 bulan, jadi intervalnya beragam,

2) media koleksi data berupa komputer dan bentuk lainnya seperti manual,

3) metode umpan balik dari hasil penilaian kinerja seperti untuk pengembangan karyawan dan kebijakan perusahaan dalam hal kompensasi, pengembangan sumberdaya manusia, dan lingkungan kerja yang nyaman, dan

4) pengembangan sistem penilaian;

$>$ mulai dari analisis pekerjaan;

$>$ spesifikasi dimensi kinerja dan perumusan kinerja;

$>$ skala pengukuran kinerja;

$>$ pengembangan format dan program pengukuran peringkat;

$>$ pengembangan prosedur penskoran;

$>$ pengembangan proses pemberian peluang tentang saran-saran dari karyawan.

\section{PERAN GURU DALAM ADMINISTRASI PTK}

Peran guru atau pendidik dalam administrasi personalia antara lain :

1. Memberi masukan tentang keaadaan personil yang ada dan kebutuhan personil akan datang.

2. Berperan aktif sesuai dengan fungsinya, sehingga pelayanan organisasi atau sekolah dapat dicapai secara optimal.

3. Menyediakan dan melengkapi sarana dan prasarana yang di perlukan.

4. Memberikan informasi mengenai keadaan personil sekolah

5. Mempertanggung jawabkan tugas dan kegiatan yang dilakukan

6. Mengatur dan mengurus penggunaan tenaga-tenaga kerja

7. Mengadakan penilaian terhadap hasil pembelajaran yang telah dicapai

8. Dapat memberi masukan tentang keadaan personil yang ada dan kebutuhan personil yang akan datang.

9. Pada kegiatan pemamfaatn pembinaan dan pengembangan guru sebagai orang yang dilayani hendaknya berperan aktif sesuai dengan fungsinya, sehingga ia mendapatkan pelayanan seperti yang diharapkan dan tujuan organisasi atau sekolah dapat dicapai secara optimal.

10. Guru dituntut untuk memahami aturan-aturan kepegawaian yang berlaku dan terkait dengannya serta berusaha dengan mengalaksanakannya secara konsisten dan penuh tanggung jawab

Suatu lembaga pendidikan dalam memajukan kualitas pendidikan yang sedang ditanganinya untuk mencapai tujuan pendidikan maka membutuhkan peran dari masing-masing menejemen sesuai dengan bidangnya. Manajemen personalia merupakan bagian manajemen yang memperhatikan orang-orang dalam organisasi, yang menjadi salah satu sub sistem manajemen.

Adapun tugas manajer dalam mewujudkan keberhasilan pendidikan yakni ia harus memperhatikan segala sesutu mengenai personalia mulai dari merencanakan, merekrut, menyeleksi, meneliti untuk perbaikan hingga memberhentikan atau memberi pensiun pegawai hal tersebut dilakukan karna merupakan kunci keberhasilan pendidikan.

Terkadang, meskipun secara konsep personalia pendidikan merupakan kunci keberhasilan pendidikan namun faktanya mereka kurang mendapat perhatian dari manajer. Pembahasan dalam rapat-rapat atau seminar hanya membahas mengenai kurikulum mengenia proses belajar mengajar, namun pembahasan mengenai bagaimana cara agar proses belajar mengajar dapat dilaksanakan oleh tenaga pengajar hampir tidak pernah dibahas.

Maka dari itu untuk menghindari penyebab kegagalan inovasi dalam proses belajar mengajar sebaiknya para manager pendidikan memberikan perhatiannya kepada personalia yang sama besarnya dengan sub sistem manajemen yang lain. Diharapkan dengan perhatian yang sama besar, manajer dapat mewujudkan perilaku organisasi pada setiap anggota organisasi. Manajer dapat melakukan tugas bila ia melaksanakan peranannya dengan sebaik-baiknya. Adapun peran personalia dalam menejemen pendidkan diataranya sebagai berikut:

1) Memiliki angan-angan sosial,

Maksud dari anagan-anagan sosial itu bahwa manager dapat menegakkan prinsip-prinsip kemanusiaan, memperhatikan moral dan etika bawahannya, membuat para bawahan tertarik akan tugas, dan meningkatkan kesejahteraan mereka. Manager akan bertindak sebagai konselor terhadap masalah-masalah pribadi, bertindak sebagai pendamai jika terdapat pertentangan antar kelompok, 
dan ia akan berusaha memecahkan masalah yang timbul dalam organisasi.

2) Sebagai konselor,

3) Pendamai,

4) Pemecah masalah,

5) Agen perubahan,

6) Rasio personalia,

7) Tugas campuran, dll:

Sebelumnya telah dijelaskan bahwa managemen personalia pendidikan bertujuan untuk mendaya gunakan tenaga kependididkan secara afektif dan efisien untuk mencapai hasil yang optimal namun tetap dalam kondisi yang menyenangkan. Sehubungan dengan itu selain peran pendidik di atas juga peran manager yang harus dilaksanakan di antaranya menarik, mengembangkan, menggaji, dan memotivasi personil guna mencapai tujuan sistem, membantu anggota mencapai posisi dan standar perilaku, memaksimalkan pengembangan karier tenaga kependidikan, menyelaraskan tujuan individu dan organisasi:

Dalam managemen personilia tidak hanya manager saja yang mendaya gunakan lembaga pendidikan namun tenaga kependidikan pun mempunyai peran dalam memajukan sekolah yang mencakup perencanaan pegawai, pengadaan pegawai, pembinaan dan pengembangan pegawai, promosi dan mutasi, pemberhentian pegawai, kompensasi, dan penilaian pegawai. Agar apa yang diharapkan tercapai maka perlu dilakukan dengan baik dan benar, dengan tenaga kependidikan yang diperlukan yaitu tenaga yang mempunyai kualivikasi dan kemampuan yang sesuai serta dapat melaksanakan pekerjaan dengan baik dan berkualitas.

Perencanaan pegawai merupakan kegiatan untuk menentukan kebutuhan pegawai, baik secara kuantitatif dan kualitatif untuk sekarang dan masa depan dalam penyusuanan rencana yang baik dan tepat memerlukan informasi yang lengkap dan jelas tentang pekerjaan atau tugas yang harus dilakukan dalam organisasi. Untuk itu sebelum menyusun rencana perlu dilakukan analisis pekerjaan dan analisis jabatan untuk memperoleh diskripsi pekerjaan.

Kemudian pengadaan pegawai merupakan kegiatan untuk memenuhi kebutuhan pegawai pada suatu lembaga, baik jumlah maupun kualitasnya. Untuk itu dilakukan kegiatan rekruitmen yaitu usaha untuk mencari dan mendapatkan calon-calon pegawai yang memenuhi syarat sebanyak mungkin, untuk kemudian dipilih calon terbaik dan tercakap.

Kebutuhan akan jumlah tenaga kependididkan memang sudah direncanakan oleh pemerintah untuk jangka waktu tertentu dengan maksud pemerintah mencetak guru-guru sementara yang disebut program diploma. Dalam hubungan ini para manager pendidikan tinggal menerima rincian dari pemerintah yang menjadi masalah ialah belum semua lembaga pendidikan menerima dan memiliki tenaga-tenaga kependidikan yang mencukupi.

Adapun fungsi pembinaan dan pengembangan pegawai merupakan fungsi pengelolaan personil yang mutlak perlu, untuk memperbaiki, menjaga, dan meningkatkan kinerja pegawai. Kegiatan ini terdapat dilakukan dengan cara on the job training dan in service training. Kegiatan pembinaan dan pengembangan ini tidak hanya menyangkut aspek kemampuan, tetapi juga menyangkut karir pegawai. Kemudian mengenai pemberhentian pegawai merupakan fungsi personelia yang menyebabkan terlepasnya pihak organisasi dan personil dari hak dan kewajiban sebagai lembaga tempat bekerja dan sebagai pegawai.

Dalam kaitannya dengan tenaga kependidikan di sekolah, khususnya pegawai negeri sipil sebab-sebab pemberhentian pegawai dapat dikelompokkan ke dalam tiga jenis: pemberhentian atas permohonan sendiri , pemberhentian oleh dinas atau pemerintahan, dan pemberhentian sebab lain-lain. Mengenai fungsi kompensasi adalah balas jasa yang diberikan organisasi pada pegawai, yang dapat dinilai dengan uang dan mempunyai kecenderungan diberikan secara tetap. Pemberian kompensasi selain dalam bentuk gaji atau dapat juga berupa tunjangan , fasilitas perumahan, kendaraan dan lain-lain.

Untuk melaksanakan fungsi-fungsi tersebut sistem penilaian pegawai secara objektif dan akurat sangat diperlukan. Penilaian prestasi individu dan peran sertanya dan kegiatan sekolah merupakan penilaian yang di fokuskan kepada tenaga pendidik. Tugas kepala sekolah kaitannya dengan managemen tenaga kependidikan bukanlah pekerjaan yang mudah karena tidak hanya mengusahakan tercapainya tujuan sekolah tetapi juga tujuan tenaga kependidikan secara pribadi untuk itu pengerjaan instrumen pengelolaan tenaga kependidikan merupakan tugas yang harus dilakukan oleh kepala sekolah.

\section{KESIMPULAN}

Pendidik profesional dengan tugas utama mendidik, mengajar, membimbing, mengarahkan, melatih, menilai, dan mengevaluasi peserta didik pada pendidikan anak usia dini jalur pendidikan formal, pendidikan dasar, dan pendidikan menengah. Administrasi pendidik dan tenaga kependidikan adalah proses keseluruhan kegiatan pendidik yang meliputi perencanaan, pengorganisasian, pengarahan, pelaporan, pengkoordinasian, pengawasan dan pembiayaan, dengan menggunakan atau memanfaatkan fasilitas yang tersedia, baik personil, materiil, maupun spirituil untuk mencapai tujuan pendidikan secara efektif dan efisien.

Administrasi pendidik merupakan mediator untuk kelancar dan keberhasil serta peningkatan efektifitas dan lainlain untuk mencapai tujuan pendidikan itu sendiri.

Sekarang, guru harus memperhatikan kepentingankepentingan sekolah, ikut serta menyelesaikan berbagai persoalan yang dihadapi sekolah, yang kadang-kadang sangat 
kompleks sifatnya, masalah-masalah administratif seperti ini sangat mempengaruhi status profesionil guru.

\section{Daftar Pustaka}

Afriansyah, Hade. 2019. Artikel Konsep Dasar, Proses, dan Ruang lingkup Administrasi Pendidikan. Padang. https://mfr.osf.io/render?url=https://osf.io/emzvn/?direct $\% 26$ mode $=$ render $\% 26$ action $=$ download $\% 26$ mode $=$ rende r

Arikunto, suharsimi. 1990.Organisasi dan Administrasi. Jakarta: CV. Raja wali

Asnawir.2005.Administrasi pendidikan. Padang: IAIN IB PRESS

Gunawan, ary. 2002. Administrasi sekolah. Jakarta: PT RINEKA CIPTA

Rifai, Moh. 1984. Administrasi dan supervise pendidikan 1. Bandung: JEMMARS

Sabri, Ahmad. 2000. Administrasi pendidika.Padang: IAIN IB PRESS 